\title{
Oxidative stress as a mediator of cardiovascular disease
}

\author{
Maqsood M. Elahi,' Yu Xiang Kong² and Bashir M. Matata,*
}

\begin{abstract}
${ }^{1}$ Wessex Cardiothoracic Centre; BUPA Hospital; Chalybeate Close; Southampton, UK; ${ }^{2}$ Department of Cardiothoracic Surgery; St. Vincent's Hospital; Melbourne, Victoria Australia; ${ }^{3}$ The Liverpool Heart \& Chest Hospital NHS Trust; Liverpool, UK
\end{abstract}

Key words: molecular mediators, redox, NO synthase, the cyclooxygenases, NAD(P)H oxidase isoforms

During physiological processes molecules undergo chemical changes involving reducing and oxidizing reactions. A molecule with an unpaired electron can combine with a molecule capable of donating an electron. The donation of an electron is termed as oxidation whereas the gaining of an electron is called reduction. Reduction and oxidation can render the reduced molecule unstable and make it free to react with other molecules to cause damage to cellular and sub-cellular components such as membranes, proteins and DNA. In this paper, we have discussed the formation of reactive oxidant species originating from a variety of sources such as nitric oxide (NO) synthase (NOS), xanthine oxidases $(X O)$, the cyclooxygenases, nicotinamide adenine dinucleotide phosphate $(\mathrm{NAD}(\mathrm{P}) \mathrm{H})$ oxidase isoforms and metal-catalyzed reactions. In addition, we present a treatise on the physiological defences such as specialized enzymes and antioxidants that maintain reduction-oxidation (redox) balance. We have also given an account of how enzymes and antioxidants can be exhausted by the excessive production of reactive oxidant species (ROS) resulting in oxidative stress/ nitrosative stress, a process that is an important mediator of cell damage. Important aspects of redox imbalance that triggers the activity of a number of signaling pathways including transcription factors activity, a process that is ubiquitous in cardiovascular disease related to ischemia/reperfusion injury have also been presented.

\section{Introduction}

Free radicals are molecules containing one or more unpaired electrons in atomic or molecular orbitals. ${ }^{1}$ Reactive free radicals play a crucial part in different physiological processes ranging from cell signaling, inflammation and the immune defense. ${ }^{2}$ There is increasing evidence that abnormal production of free radicals lead to increased stress on cellular structures and causes changes in molecular pathways that underpins the pathogenesis of several important human diseases, including heart disease, neurological disease and cancer and in the process of physiological ageing. ${ }^{3,4}$ Understanding the contribution of free radical stress in the

*Correspondence to: Bashir M. Matata; Email: matata_bashir@hotmail. com

Submitted: 06/25/09; Revised: 07/07/09; Accepted: 07/07/09

Previously published online:

www.landesbioscience.com/journals/oximed/article/944I pathogenesis of disease will allow us to study the development of oxidative stress; a condition that occurs due to an imbalance between cellular production of oxidant molecules and the availability of appropriate antioxidants species that defend against them. It is hoped that this knowledge will subsequently lead to the development of effective therapeutic interventions against oxidative stress.

One of the major contributors of oxidative stress is the reactive oxygen species (ROS) family of molecules. These include free radicals such as superoxide anion $\left(\mathrm{O}_{2}^{-}{ }^{-}\right)$, hydroxyl radical $(\mathrm{HO})$, lipid radicals ( $\left.\mathrm{ROO}^{-}\right)$and nitric oxide (NO). Other reactive oxygen species, hydrogen peroxide $\left(\mathrm{H}_{2} \mathrm{O}_{2}\right)$, peroxynitrite (ONOO-) and hypochlorous acid $(\mathrm{HOCl})$, although are not free radicals but they have oxidizing effects that contribute to oxidative stress. ROS has been implicated in cell damage, necrosis and cell apoptosis due to its direct oxidizing effects on macromolecules such as lipids, proteins and DNA. ${ }^{5}$ Production of one free radical can lead to further formation of radicals via sequential chain reactions. ${ }^{6}$ Reactions between radicals and polyunsaturated fatty acids within cell membrane can result in fatty acid peroxyl radicals, which accumulate in cell membrane and alter protein function and signal transduction. Under oxidative stress, excessive superoxide also releases free iron from iron-containing molecules, which further generate highly reactive hydroxyl radicals (HO) by reacting with hydrogen peroxide in the Fenton reaction. ${ }^{7}$ ROS can also induce the opening of the mitochondria membrane permeability transition pore (PTP) and cause a release in cytochrome $c$ and other factors that can lead to apoptosis-mediated cell death. ${ }^{8,9} \mathrm{O}_{2}$ - radicals can further interact with the signaling molecule nitric oxide (NO) resulting in the formation of reactive nitrogen species (RNS), which further reduce NO bioavailability and cause NO toxicity known as "nitrosative stress". ${ }^{10}$ Like ROS, excessive production of reactive nitrogen species results in nitrosylation reactions that change the structure of proteins, leading to loss or change of protein function. ${ }^{11}$

In physiological conditions, cells would increase activities of antioxidant enzymes and other antioxidant defences to counteract occurrence of oxidative stress. ${ }^{12-14}$ These include manganese dependent superoxide dismutase such as manganese superoxide dismutase (Mn-SOD), Copper/Zinc superoxide dismutase (Cu/Zn SOD), glutathione peroxidase, glutathione reductase and catalase (CAT). MnSOD and $\mathrm{Cu} / \mathrm{ZnSOD}$ convert $\mathrm{O}_{2}$ to hydrogen peroxide, which is then transformed to water by glutathione peroxidase or catalase. Other antioxidant defences 


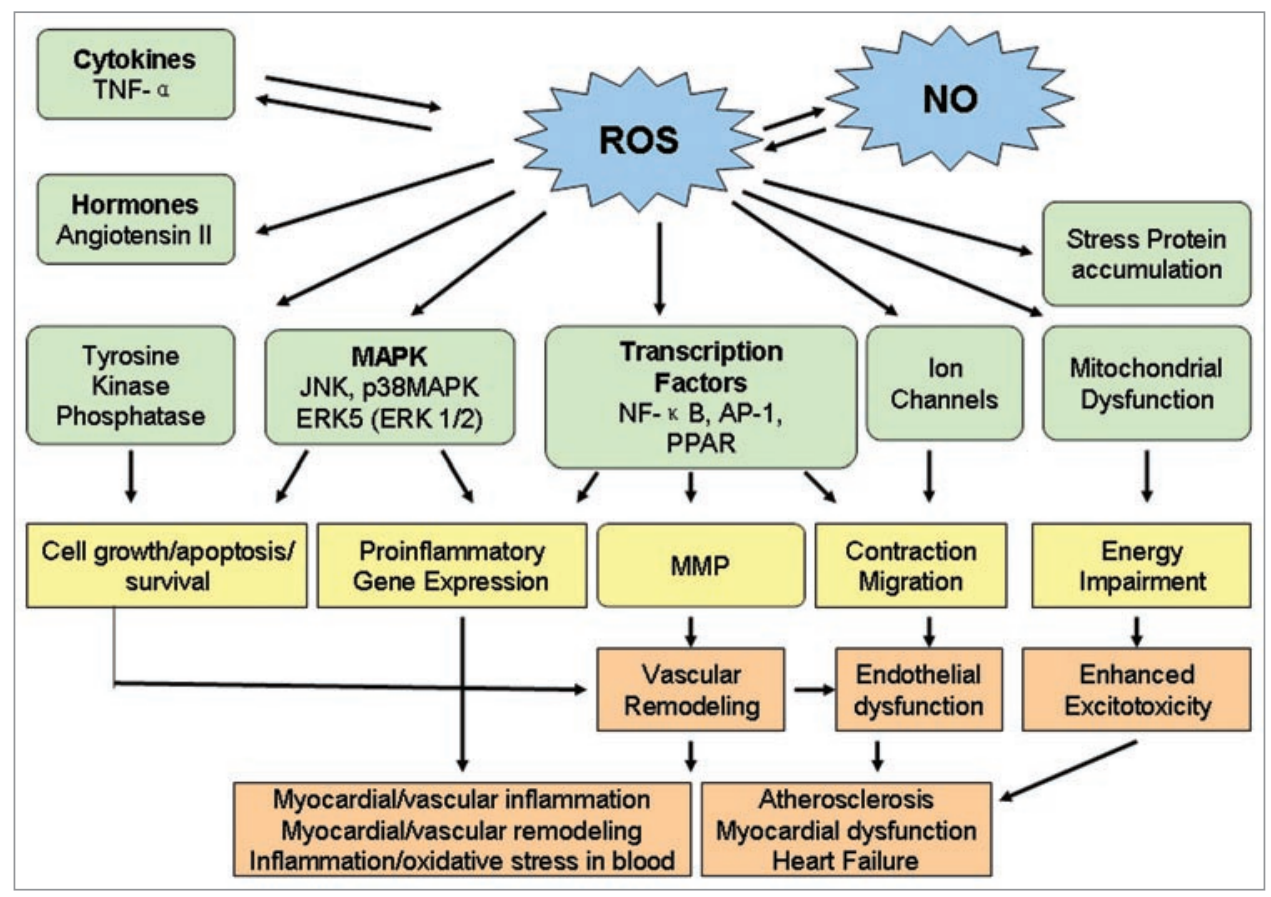

Figure I. In physiological and disease states, the involvement of the inflammatory state initiated within cellular environment. This entails increased activities of antioxidant enzymes and other antioxidant defences to counteract occurrence of oxidative stress mainly characterised by nitric oxide (NO) and reactive oxygen species (ROS). This molecular fiasco illustrates into cellular pathways that regulate redox status of cells and the consequence of imbalance between free radical production and antioxidant activity during the cardiovascular disease process.

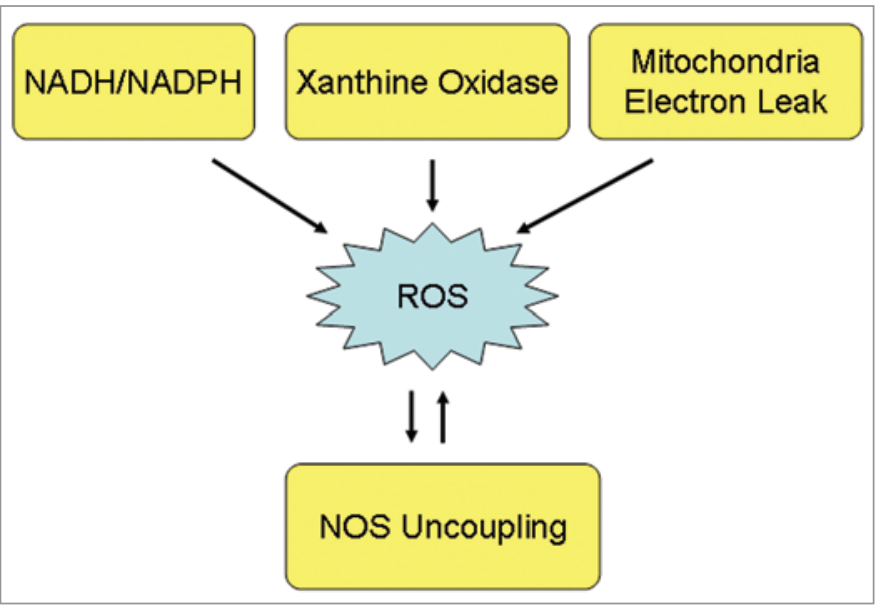

Figure 2. Several interlinked pathways that include mitochondria respiration, NADPH oxidases, xanthine oxidase and uncoupled NO synthases are associated with the production of free radicals within cells under physiological conditions. Mitochondria produce significant amounts of cellular ROS via aberrant $\mathrm{O}_{2}$ reaction. This rate of mitochondrial respiration and ROS formation is largely influenced by the coupling state of the mitochondria, and in turn by factors such as internal and external $\mathrm{Ca}^{2+}$ levels and antioxidant activity. In response to the presence of respiratory burst explained in the text, NADPH oxidase activity get modulated by upregulation of component mRNAs and other inflammatory mediators such as TNFalpha thus dependent on the increase in transcription of 222 phox, an important subunit of $\mathrm{NAD}(\mathrm{P}) \mathrm{H}$ oxidase. include radical scavengers such as vitamin $\mathrm{E}$, beta carotene and vitamin C.

This article aims to illustrate in detail, molecular pathways that regulate redox status of cells and the consequence of imbalance between free radical production and antioxidant activity during the cardiovascular disease process (Fig. 1).

\section{Physiological Sources of Reactive Oxidant Species in Cells}

Several mechanisms or pathways are associated with the production of free radicals within cells under physiological conditions. These include mitochondria respiration, nicotinamide adenine dinucleotide phosphate (NADPH) oxidases, xanthine oxidase and uncoupled NO synthases (Fig. 2).

Mitochondrial respiration as a source of reactive oxidant species in cells. Mitochondrial respiration involves transport of electrons from NADH or flavoprotein-linked dehydrogenases which ultimately result in reduction of oxygen to water, producing ATP in the process. This transport chain involves oxidative phosphorylation (OxPHOS) of complexes that are both nuclear and mitochondrial DNA encoded. Mitochondria produce significant amounts of cellular reactive oxidant species (ROS) via aberrant $\mathrm{O}_{2}$ reaction..$^{15,16}$ During electron transport, approximately $2-5 \%$ of electrons escape to react with $\mathrm{O}_{2}$ resulting in the production of ROS, which primarily occur at complexes I and III. ${ }^{17}$ This process in physiological conditions is tightly controlled with majority of ROS produced remaining inside intact mitochondria. ${ }^{18}$ In addition, some elements of the mitochondrial outer membrane 


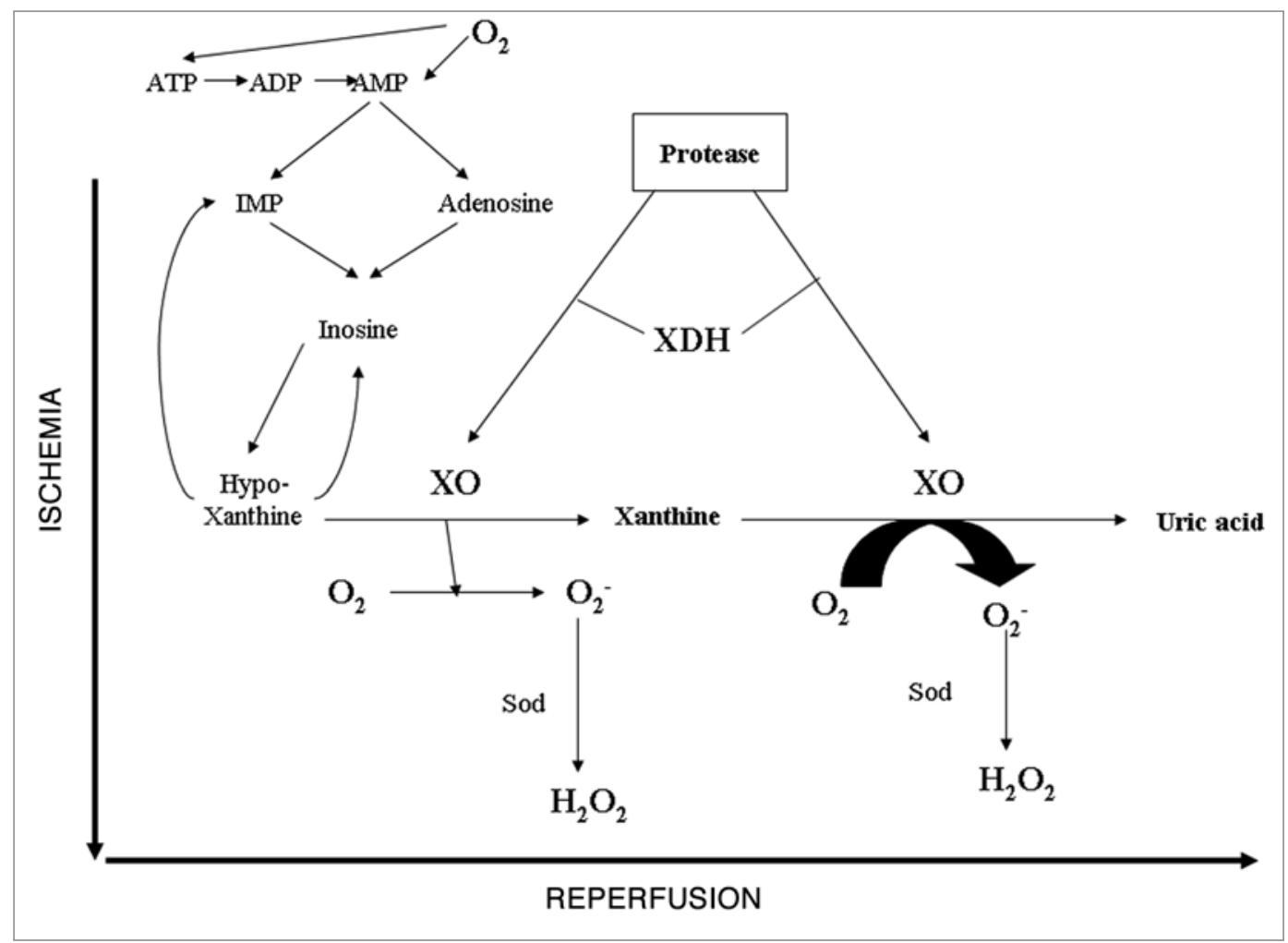

Figure 3. Proposed mechanism of xanthine oxido-reductase pathways. The enzymatic inhibition results in an increased availability of hypoxanthine for purine nucleotide synthesis via 5'-nucleotidase and inosine monophosphate (IMP) and adenosine monophosphate (AMP) dephosphorylation, thereby facilitate dissipating adenosine triphosphate (ATP) synthesis. On one hand, transmembrane ion gradients push cytosolic concentrations of calcium to rise, which in turn, activities protease that irreversibly converts xanthine dehydrogenase (XDH), predominant in vivo, in to xanthine oxidase (XO). At the same time, cellular ATP is catabolised to hypoxanthine, which accumulates in the diseased cell. During the reperfusion phase, XO using readmitted oxygen and hypoxanthine generates superoxide and hydrogen peroxide. Scheme derived from Puig et al., 1989.140

such as monoamine oxidases produce $\mathrm{NO}$ or $\mathrm{H}_{2} \mathrm{O}_{2}$ which result in increased free radical stress. ${ }^{19}$ The rate of mitochondrial respiration and ROS formation is largely influenced by the coupling state of the mitochondria, and in turn by factors such as internal and external $\mathrm{Ca}^{2+}$ levels and antioxidant activity. $\mathrm{Mn}-\mathrm{SOD}$ located in the mitochondrial matrix is an important antioxidant regulating ROS production.

The balance between oxidants and antioxidants commonly termed "redox state" of mitochondria also influences the opening of mitochondrial permeability transition pore (MPTP), which is associated with energy uncoupling and further ROS production ${ }^{20}$ and development of disease process. For instance, overproduction of mitochondrial ROS/NO is associated with early atherosclerosis and hypercholesterolemia. Mitochondrial ROS is also linked to vascular cell pathology from hyperglycaemia induced glycation and protein kinase $\mathrm{C}$ activation. ${ }^{21}$ Mitochondrial source of $\mathrm{H}_{2} \mathrm{O}_{2}$ play a key role in flow-mediated dilatation in human coronary resistance arteries. ${ }^{22}$

In endothelial cells hypoxia induces ROS generation and decreases activator protein-1 (AP-1) transcriptional activity, shown to be limited by inhibition of mitochondrial complex III with myothioxol, which suggest mitochondrial ROS are involved in hypoxia-induced signaling. ${ }^{23}$
NADH/NADPH oxidase system as a source of reactive oxidant species in the cell. NADH/NADPH oxidases are membrane-associated enzymes that catalyse the 1-electron reduction of oxygen using NADH or NADPH as the electron donor. NADPH is particularly important in generation of ROS in phagocytic cell systems in response to the presence of foreign organisms in a series of changes known as "respiratory burst". ${ }^{24} \mathrm{NADH} / \mathrm{NADPH}$ oxidases are also important sources of endovascular ROS. NADH/ NADPH oxidases are the major oxidases in vascular tissue and in cardiac cells. ${ }^{25}$

$\mathrm{NADH} / \mathrm{NADPH}$ activity is regulated by a number of factors known to be involved in the pathogenesis of cardiovascular disease including cytokines, hormones, local metabolic changes and haemodynamic forces. Exposure of human umbilical endothelial cells to $5-20$ dyne $/ \mathrm{cm}^{2}$ unidirectional lamina shear stress results in a transient elevation in $\mathrm{NADH}$-dependent $\mathrm{O}_{2}-$ formation whereas oscillatory shear causes sustained increase in oxidase activity. ${ }^{26} \mathrm{NADH} / \mathrm{NADPH}$-dependent oxidase activity is also increased in vascular smooth muscle cells by stimulation with the vasoactive agonist angiotensin II. Angiotensin II increases $\mathrm{NADH}$ and $\mathrm{NADPH}$ driven $\mathrm{O}_{2}$ - production in cultured vascular smooth muscle cells (VSMC) and aortic adventitial fibroblasts. ${ }^{27}$ $\mathrm{NADH} / \mathrm{NADPH}$-dependent $\mathrm{O}_{2}$ - formation is increased in experimental rat model of angiotensin II-induced hypertension. ${ }^{25}$ 
Activation of the oxidase can be mediated by intracellular second messengers. ${ }^{28}$ For instance, lipoxygenase metabolites of arachidonic acid mediate angiotensin II stimulation of NAD(P) $\mathrm{H}$ oxidase in VSMC. ${ }^{29}$ Furthermore oxidase activity can also be modulated by upregulation of component mRNAs. TNFalpha increases NAD(P)H oxidase activity in VSMC over 24 hours, which is dependent on the increase in transcription of p22phox, an important subunit of NAD $(\mathrm{P}) \mathrm{H}$ oxidase. ${ }^{30}$

Treatment with exogenous antioxidant SOD improves blood pressure and vascular reactivity in rat model of angiotensin II induced hypertension. ${ }^{31}$ Re-oxygenation following a period of hypoxia is accompanied by an increase in lactate that stimulates $\mathrm{NADH}$ oxidase activity in cardiac myocytes. ${ }^{32}$ Various factors including thrombin, platelet-derived growth factor, and cytokines such as tumor necrosis factor-alpha (TNFalpha) also induce NADH/NADPH-dependent oxidase activity. ${ }^{30,33}$ Elevated levels of NADH-dependent $\mathrm{O}_{2}$ - have been found to be associated with diabetes and hypercholesterolemia in human saphenous vein segments obtained from patients undergoing coronary artery bypass surgery ${ }^{34}$ and in cardiac remodelling following myocardial infarction. ${ }^{35}$

Xanthine oxido-reductase system as a source of reactive oxidant species in the cell. Xanthine oxido-reductase exists in two interconvertible forms, either as xanthine dehydrogenase or xanthine oxidase. ${ }^{36}$ The first form reduces $\mathrm{NAD}^{+}$whereas the latter reacts with molecular oxygen, leading to the production of superoxide anion and hydrogen peroxide. ${ }^{37}$ In the purine catabolism, xanthine oxido-reductase catalyses oxidative hydroxylation of hypoxanthine to xanthine, and then from xanthine to uric acid, which is a strong antioxidant and a free radical scavenger (Fig. 3). The dual role of xanthine oxidase means that it is an important regulator of cellular redox state.

Under pathophysiological stress conditions, xanthine oxido-reductase is an important source of oxidative stress. ${ }^{13}$ In experimental atherosclerosis caused by diet induced hypercholesterolemia, excess superoxide production was inhibited using oxypurinol, a xanthine oxidase inhibitor. ${ }^{38}$ Xanthine oxidase generates ROS via purine metabolism pathway and is involved in causing endothelial dysfunction in patients with coronary disease and contractile dysfunction in heart failure. ${ }^{39}$

NOS uncoupling as a source of reactive oxidant species in the cell. Uncoupled NO Synthase (NOS) contribute to ROS generation and result in vascular endothelial dysfunction. ${ }^{40,41}$ Endothelial NOS (eNOS) is a cytochrome $\mathrm{P} 450$ reductase-like enzyme that catalyses flavin-mediated electron transport from the electron donor NADPH to a prosthetic heme group. NOS are the major source of endogenous NO. eNOS can produce both NOS via its oxygenase function and superoxide through its reductase function, the later dependent on NADPH. This enzyme requires tetrahydrobiopterin (BH-4) bound near this heme group to transfer electrons to guanidino nitrogen of L-arginine to form nitric oxide (NO). ${ }^{42}$ Uncoupling of eNOS contribute to ROS when deficiency of L-arginine or $\mathrm{BH}-4 .{ }^{43}$ In the absence of $\mathrm{L}$-arginine or $\mathrm{BH}-4$, eNOS can produce $\mathrm{O}_{2} \cdot-$ and $\mathrm{H}_{2} \mathrm{O}_{2} \cdot{ }^{41}$ The product of reaction between $\mathrm{NO}$ and $\mathrm{O}_{2}{ }^{-}$can oxidize $\mathrm{BH}_{4}$ and this may lead to further eNOS uncoupling. ${ }^{44}$
$\mathrm{NO}$ is a major cell signaling molecule involved in a large variety of different physiological processes including neurotransmission, regulation of vascular dynamics and immune regulation. ${ }^{45}$ It is one of the main mediators of endothelium-dependent relaxation (EDR). NO release is induced by either vascular shearstress or by eNOS activation in response to cytokine activation ${ }^{46}$ and plays a protective role in suppressing abnormal proliferation of vascular smooth muscle cells (VSMCs) following various pathological situations. ${ }^{47} \mathrm{NO}$ has been shown to react with and cancelled by reaction with excess ROS directly inactivating it. ${ }^{48} \mathrm{O}_{2}$-- reacts with $\mathrm{NO}$ to produce peroxynitrite, which reduces bioavailability of $\mathrm{NO}$ and produces more damaging secondary species. ROS may also affect $\mathrm{NO}$ responses by oxidizing sites on the protein that reacts with $\mathrm{NO}$ (direct competition) or which would otherwise influence NO binding (allosteric modulation). There concentration of NOS in blood vessels is therefore dependent on the balance between production of $\mathrm{NO}$ on one hand and destruction by ROS on the other. Xanthine oxidase and NADPH oxidases are inhibited by NO, thereby NOS activity also regulate free radical production and maintain ROS/NO homeostasis. ${ }^{49}$ Evidence of eNOS contribution to cellular ROS is present in the context of hypercholesterolemia, ${ }^{50}$ atherosclerosis, ${ }^{51}$ coronary artery disease, ${ }^{52}$ aging and diabetes. ${ }^{53}$

Imbalance between endothelial NO and ROS production is one of the major contributor of endothelial dysfunction which plays an important part in atherosclerosis and cardiac disease. ${ }^{54}$

\section{Regulation of Physiological Function and Disease Process by Reactive Oxidant Species Signaling}

In addition to its direct damaging effect on macromolecules, ROS can act as biochemical messengers that regulate various intracellular signaling pathways. ROS have been implicated in regulation of calcium $\left(\mathrm{Ca}^{2+}\right)$ induced signaling in the vasculature which in turn can activate calcium dependent protein kinases activity such as PKC and calcineurin. ${ }^{55}$ Intracellular ROS also affect the activity of protein kinase pathways by influencing the redox state of the cell. Alterations in the redox state of protein cysteinyl residues result in changes in protein conformation and function. Influence of Tyrosine kinase activity by ROS has been observed in a variety of cell types. ${ }^{55}$ Stimulation of vascular smooth muscle cell (VSMC) by platelet-derived growth factor (PDGF) transiently increases $\mathrm{H}_{2} \mathrm{O}_{2}$ production that induces tyrosine phosphorylation, mitogen activated protein kinase (MAPK) activation and chemotaxis, effects that were not observed in the higher intracellular concentration of the antioxidant $\mathrm{N}$-acetylcysteine. ${ }^{43}$ Stimulation of VSMC with $\mathrm{O}_{2}{ }^{--}$generating agent LY83583 also resulted in the increase of MAPK activity in a concentration dependent manner. ${ }^{56}$ LacCer, a glycosphingolipid implicated in the proliferation of VSMC and atherosclerotic plaque formation has also been shown to stimulate $\mathrm{O}_{2}$ - production, activation of NADPH and MAPK pathway induction. ${ }^{57}$

Gene expression pattern is also regulated by ROS via modulation of transcription factor activity particularly nuclear factor kappaB (NFאB), AP-1 and the peroxisome proliferators- 
activated receptor (PPAP) family of transcriptional activators ${ }^{2}$ where redox cycling of cysteinyl residues plays an important part in this transcription factor regulation process. ${ }^{58}$

ROS signaling via NFKB activation. $\mathrm{NF \kappa B}$ is one of the most commonly studied transcriptional factors influenced by cellular redox state. ${ }^{59} \mathrm{NF \kappa B}$ is a family of inducible transcription factors first described as B-lymphocyte-specific nuclear proteins essential for transcription of immunoglobulin kappa ( $(\kappa)$ light chains. It is important in regulation of inflammation, stress responses, expression of cytokines and cell adhesion molecules, regulation of immune response and programmed cell death. ${ }^{60}$

NFKB forms functional dimerized structure composed of members of the Rel family, which include p65 (RelA), NFкB1(p50), NFкB-2(p52), c-Rel and RelB. ${ }^{61}$ Members of the Rel family carry a Rel homology domain which contains a nuclear localization signal (NLS). The homodimers and hetero-dimers are kept inactive by structurally association with $\mathrm{I} \kappa \mathrm{B}$ family of inhibitory proteins in the cytoplasm including I $\mathrm{\kappa} B-\mathrm{a}, \mathrm{I} \kappa \mathrm{B}-\mathrm{b}$, IкB-e, as well as p105 and p100 precursors of p50 and p52. ${ }^{62}$

Dissociation of $\mathrm{NF \kappa B}$ from its $\mathrm{I} \kappa \mathrm{B}$ inhibitory protein is the initial step of $\mathrm{NF \kappa B}$ activity. Upon activation by stimulatory signals phosphorylation of I $\mathrm{B}$ by ubiquitin-dependent protein kinase results in its ubiquitination and proteolytic degradation. Amino acid residues Ser-32 and Ser-36 of IкB are essential for phosphorylation and Lys-21 and Lys-22 are important for ubiquitination process. The activated NFKB rapidly translocate to the nucleus to regulate $\mathrm{NF \kappa B}$ responsive genes. ${ }^{63}$ Members of $\mathrm{I} \kappa \mathrm{B}$ are also nuclear transcription factors that interact with $\mathrm{NF} \kappa \mathrm{B}$ family members directly in the nucleus, influencing its function. Many of the stimuli related to atherosclerosis are upstream regulators of NFKB such as oxidized LDL, cytokines (TNF $\alpha$, IL-1), UV light, ionizing radiation and infectious agents.

ROS is an important intermediate second messenger of NFKB activation by upstream stimuli such as TNF and IL-1. ${ }^{64}$ Antioxidants including vitamin $\mathrm{E}$ and $\mathrm{N}$-acetylcysteine have been shown to reverse activation of NFKB by stimuli, ${ }^{65}$ however it is thought that a non-antioxidant action on NFKB activity may also be responsible. ${ }^{65}$

NFKB cooperates with other transcription factors in orchestrating gene expression. The interaction between $\mathrm{NF \kappa B}$ and AP-1 is particularly important as many genes involved in the regulation of inflammation require both transcription factors working together. ${ }^{66}$ The modulation of NFKB signaling is affected by post-translational modifications, including reversal acetylation of the RelA/p65 subunit. Full transcriptional activity of RelA/p65 requires the acetylation of locus Lys-310, which can be deaceytylated by sirtuin-1 (SIRT1), a class II histone deacetyl transferase. ${ }^{67}$ The small molecular agonist of SIRT1, Resveratrol, has been shown to inhibit NFKB signaling by promoting the deacetylation of RelA/p65. ${ }^{68}$

NFKB induce the transcription of more than 200 genes, of which many are involved in regulation of inflammation, the production of cytokines, and upregulation of prothrombotic markers, processes associated with pathogenesis of atherosclerosis. ${ }^{69} \mathrm{NF \kappa B}$ is found to be upregulated in atherosclerotic vessels ${ }^{70}$ and its nuclear translocation has been detected in the intima and media of atherosclerotic lesions and in smooth muscle cells, endothelial cells, macrophages and $\mathrm{T}$ cells of atherosclerotic plaques. ${ }^{71}$ It has also been reported that $\mathrm{NF \kappa B}$ also plays a role in mediating T-cell signaling in atheromatous plaques. ${ }^{72,73}$

Cardiac specific blockade of NFKB in rodents has been shown to reduce myocardial infarct size following ischaemia/reperfusion injury. NFKB knockout mice have also been shown to have a decreased infarct size and improved haemodynamics after ischaemia/reperfusion injury, although the effects have not been seen in the long term. ${ }^{74}$

NFKB activation in atherosclerosis can be due to several factors. Local vascular injury has been shown to decrease inhibitory protein $\mathrm{I} \kappa \mathrm{B}$ and result in increased macrophage infiltration. ${ }^{75}$ Localized adventitial hypoxia has been implicated in NFKB activation. ${ }^{76}$ Oxidized low density lipoprotein (LDL) which is implicated to plays a major role in atherosclerosis formation also regulate $\mathrm{NF \kappa B}$ activity. In an in vivo study, injected LDL particles localised to arterial walls and underwent oxidative modification and subsequent activation of endothelial NFKB activity and expression of NFKB-dependent genes. ${ }^{77}$ Advanced glycation end products (AGEs) formed through non-enzymatic reactions of sugars with amino groups of proteins, nucleotides and lipids have also been shown to accumulate in atherosclerotic plaques and are thought to activate monocytes infiltration through NFKB. ${ }^{78}$ Furthermore the hormone angiotensin II, in addition to its effects on blood pressure also participates in the formation of atherosclerosis through expression of adhesion molecules and IL-6 in smooth muscle cells, this process is partly regulated through NFkB. ${ }^{79}$

Involvement of infectious agents has been implicated in the pathogenesis of atherosclerosis. Expression of Toll Like Receptors (TLR), found to activate $\mathrm{NF \kappa B}$, are involved in the initial recognition of pathogenic antigens such as bacterial lipopolysaccharides have been found to be upregulated in human atherosclerotic arteries compared to low levels in normal arteries. ${ }^{80}$

ROS signaling via AP-1 activation. AP-1 is a family of basic domain/leucine zipper (bZIP) transcription factors characterized by their specific trans-activation through the cis-acting transcriptional control DNA element, the 12-O-tetradecanoyl phorbol13-acetate (TPA) response element (TRE). AP-1 is a heterodimer of members of FOS and JUN families, or a homodimer of JUN proteins. ${ }^{81}$

AP-1 activity is controlled by both transcriptional and posttranslational mechanisms in response to variety of extracellular stimuli. ${ }^{82}$ The expression of c-JUN and c-FOS is induced by various mitogens ${ }^{83}$ such as hydrogen peroxide, ${ }^{84} \mathrm{UV},{ }^{85}$ and ionizing radiation. ${ }^{17}$ Arachidonic acid metabolite concentration and Mitogen kinase pathway activity are involved in mediating activation of AP- $1 .{ }^{86} \mathrm{AP}-1$ is also important in the regulation of gene expression of various target genes involved in cell proliferation and transformation. ${ }^{87}$

In smooth muscle cells AP-1 expression or DNA-binding activity have been shown to be upregulated by $\mathrm{H}_{2} \mathrm{O}_{2}$, oxidized LDL and lipid peroxidation. ${ }^{88}$ It is suggested that AP-1 activation under oxidative conditions may be mediated by phosphorylation 
of Jun proteins. ${ }^{89}$ However a number of antioxidants such as cysteine based redox regulators of glutathione and thioredoxin pathways have also been shown to stimulate DNA binding and transcriptional activity of AP- $1 .^{90}$ Therefore the regulation of AP-1 by oxidative free radicals is complex and requires further elucidation.

ROS signaling via peroxisome proliferators activated receptors (PPAR). The dimerisation of PPAR with retinoid X receptorbeta (RXRbeta) occurs in response to various metabolic stimuli. PPAR/RXRbeta transcription factor is responsible for inducing acetyl coenzyme A oxidase, an enzyme that transfers electrons to oxygen to produce $\mathrm{H}_{2} \mathrm{O}_{2} \cdot{ }^{91}$ PPAR transcription factor has been implicated in the inflammatory processes involved in pathogenesis of atherosclerosis. ${ }^{92}$ Oxidized LDL has been shown to increase expression of PPAR in foam cells of atherosclerotic lesions. ${ }^{93}$ However PPAR does not have a sole role in mediation of inflammation. Activation of PPARalpha and PPARgamma isoforms results in anti-inflammatory responses in blood vessel wall. Specific agonists of PPARgamma has been shown to suppress pro-inflammatory gene expression in monocytes. ${ }^{94}$ Activators of PPAR alpha has also been shown to block inflammatory responses in aortic smooth muscle cells and PPARgamma activation was recently shown to mitigate the inflammation associated with chronic and acute neurological insults. ${ }^{93}$

\section{Reactive Oxidant Species Formation and Cardiovascular Disease}

Oxidative/nitrosative and endothelial dysfunction in aterosclerosis. One of the key concepts of free radical mediated pathogenesis of cardiovascular disease is endothelial dysfunction, whereby the regulation of vascular wall microenvironment is disrupted. An important element in this concept is that vascular endothelium is an active component of the vasculature, which plays a part in the regulation of vascular tone, platelet activity, thrombosis, inflammation and atherosclerosis. Endothelium vasoactive tone is maintained by the release of substances like prostacyclins, endothelins and the endothelium-derived relaxation factor nitric oxide (NO) or a related compound. ${ }^{95}$

Reduction in endothelium-dependent vasorelaxation caused by the reduction in NO bioavailability plays a significant role in endothelial dysfunction. Decreased NO bioavailability disrupts the non-thrombogenic intimal surface and promotes platelet adhesion and aggregation as well as deposition of platelets on the abnormal endothelial surface.

Thrombus formation during acute coronary syndromes results in the release of various vasoactive substances such as thrombin and serotonin. ${ }^{96-98}$ In normal endothelium these substances mediate vasodilatation. ${ }^{99}$ In the setting of endothelial vasodilator dysfunction vasoconstriction occurs. ${ }^{100}$ This is potentiated by the presence of endothelins, whose concentrations are elevated concentration in plaques of patients with acute coronary syndrome. ${ }^{101}$

The impairment of vasodilatation in response to vasodilator acetylcholine is a measurement of endothelial dysfunction and it correlates with increased local ROS production and reduced superoxide dismutase activity. ${ }^{102}$ The lack of myeloperoxidase activity suggests that elevated leukocyte/macrophage production of ROS is not involved in the process.

Endothelial vasodilator dysfunction can lead to paradoxical vasoconstriction effects and occurs in situations with sympathetic activation such as exercise. In the cardiac vasculature this can result in angina pectoris. ${ }^{96}$ During increased metabolic demand, vasodilator dysfunction in coronary vessels has been shown to result in ischemia, even in the absence of pathological stenosis. ${ }^{99}$

Endothelium dysfunction has been observed in patients with established coronary artery disease or risk factors for both coronary and peripheral vascular disease. ${ }^{100}$ Impairment in endothelium-dependent vasorelaxation predicts adverse cardiovascular events and long-term outcomes. ${ }^{101}$

Atherosclerosis in coronary arteries even at early stages is associated with evidence of endothelium dysfunction. ${ }^{101}$ Longterm cigarette smoking is an independent risk factor for impaired endothelium-dependent coronary vasodilation regardless of the presence or absence of coronary atherosclerotic lesions. ${ }^{102}$ Studies in the human forearm have demonstrated decreased flow-dependent dilation in chronic smokers. ${ }^{103}$ The blunted endothelium dependent relaxation (EDR) was improved with antioxidant vitamin $\mathrm{C}$ in chronic smokers, indicating the involvement of ROS in the pathogenesis. ${ }^{104}$ Hypertension is also linked to increased vascular oxidative stress in a number of animal models of hypertension. ${ }^{105}$ Hypertension leads to blunting of EDR through effect of oxidative stress. ${ }^{106}$

Endothelium-dependent coronary blood flow regulation is blunted in the presence of elevated cholesterol levels. Furthermore the type of cholesterol appears to produce different response. Reduced EDR is closely related to LDL cholesterol levels but ameliorated with high HDL-levels. ${ }^{106}$

At sites of plaque growth, NO release is increased in response to increased shear-stress acting on the vessel wall. This may lead to vasodilation and structural vessel wall remodelling. ${ }^{107}$ Baseline vasomotor tone is also decreased in atherosclerotic vessels by a functional mechanism. ${ }^{108}$

Reduction in NO bioavailability can be decrease by several mechanisms including reduction in eNOS expression, lack of substrate or cofactors for eNOS activity, alterations of eNOS cellular signaling and increase in NO degradation. ${ }^{109}$ Mice with eNOS knockout are more prone to develop typical atherosclerotic lesions in response to adventitial vessel wall injury compared to wild-type mice. ${ }^{110}$

The bioavailability of NOS is more important for coronary artery dilatation than the activity of eNOS and generation of NOS. The bioavailability of NOS is influenced by the amount of ROS present that can transform $\mathrm{NO}$ to $\mathrm{ONOO}^{-}$and oxidized tetrahydrobiopterin to dihydrobiopterin which lead to eNOS uncoupling and further ROS production. ${ }^{95}$ Upregulation of tetrahydrobiopterin which improves bioavailability of NOS has been shown to improve endothelial function and reduce superoxide production. ${ }^{11}$ Supplementation of antioxidant superoxide dismutase has also been shown to improve endothelium dependent vasodilatation of coronary arteries. ${ }^{12}$ Treatment with L-arginine, precursor of intracellular NOS, has been found to improve 
endothelium dependent vasodilation in patients with cardiac risk factors. ${ }^{113,114}$ In addition, calorie restrictions for 3-12 months lead to enhanced eNOS expression and cGMP formation in various tissues in mice. ${ }^{112}$ This was accompanied by mitochondrial biogenesis, increased oxygen consumption and ATP production and enhanced expression of sirtuin-1. ${ }^{112}$ These effects were abrogated in eNOS null mutant mice. ${ }^{112}$

Furthermore NO generated by vascular endothelium has traditionally been thought to have a purely paracrine role. Interestingly, recent evidence show that NO display hormonal function by reacting with haemoglobin to form stable metabolites, which can be transported through the blood stream and subsequently release $\mathrm{NO}$ at sites distant to the site of production. ${ }^{115}$ During oxygenation in the lung some NO transfers to the highly conserved beta chain Cys93 residue of haemoglobin to produce S-nitrosyl haemoglobin (SNO-Hb). Following deoxygenation in peripheral circulation, $\mathrm{SNO}-\mathrm{Hb}$ is able to then release $\mathrm{NO}$ bioactivity. The significance of this mode of $\mathrm{NO}$ activity is still under investigation.

Oxidative/nitrosative stress and hypertension. Clinical studies have demonstrated that there is increased ROS production in patients with essential hypertension, renovascular hypertension, malignant hypertension and pre-eclampsia. ${ }^{116-119}$ Vascular ROS are produced in endothelial, adventitial and vascular smooth muscle cells (VSMCs) and derived primarily from NAD(P)H oxidase, a multi-subunit enzyme catalyzing $\mathrm{O}_{2}$ - production by the 1 electron reduction of oxygen using $\mathrm{NAD}(\mathrm{P}) \mathrm{H}$ as the electron donor: ${ }^{120}$

$$
2 \mathrm{O}_{2}+\mathrm{NAD}(\mathrm{P}) \mathrm{H} \rightarrow 2 \mathrm{O}_{2}^{-}+\mathrm{NAD}(\mathrm{P})+\mathrm{H}^{+}
$$

Interestingly, all major trials on antioxidant supplementation have failed to show significant cardiovascular benefits and antioxidants are not recommended for the prevention or treatment of hypertension. In contrast, dietary approaches are highly recommended, supported by evidence from a trial which demonstrated that subjects consuming high fruit and vegetable diets had significantly reduced blood pressure. ${ }^{121}$ On the other hand, direct cardiovascular effects of some pharmaceutical agents have been attributed to direct inhibition of $\mathrm{NAD}(\mathrm{P}) \mathrm{H}$ oxidase activity, as shown for angiotensin $1\left(\mathrm{AT}_{1}\right)$ receptor blockers, and to intrinsic antioxidant properties of the agents. Classical antihypertensive agents such as $\beta$-adrenergic blockers (carvedilol), ACE inhibitors, $\mathrm{AT}_{1}$ receptor antagonists, and $\mathrm{Ca}^{2+}$ channel blockers may be mediated, in part, by decreasing vascular oxidative stress. ${ }^{122-124}$

Oxidative/nitrosative stress and cardiovascular disease outcomes. Oxidative stress is linked with negative outcomes in cardiovascular disease. ${ }^{88}$ As discussed above, free radical stress can lead to cardiovascular disease by influencing the endothelial function. ${ }^{125}$ ROS can cause direct cardiac injury by oxidizing cellular constituents, disruption of proteins critical for excitation-contraction (E-C) coupling and by diminishing NO bioactivity. ${ }^{126}$ Blood sample from patients with ischaemic heart disease has been shown to contain evidence of oxidative/nitrosative stress. ${ }^{127}$

Oxidative/nitrosative stress and cardiovascular ischemia. In myocardial ischaemia, hypoxia and reoxygenation induces an increase in free radical production in cardiac tissues and are principal causes of reperfusion injury. ROS produced through reoxygenation lead to direct oxidative damage to cellular components and also through indirect injury via activation of localized inflammation. ${ }^{1}$ ROS can also act as signaling messenger in activating biochemical pathways responsible for altering cellular function. ${ }^{128}$ For instance, Akt activation in VSMC induced by exogenous angiotensin II, which leads to VSMC hypertrophy, has also been shown to be mediated by $\mathrm{H}_{2} \mathrm{O}_{2}$ and can be abrogated by overexpression of catalase. ${ }^{54}$ Hypoxia/reoxygenation in cardiac myocytes also leads to induction of p38 MAPK and JNK pathways and that the activity of these pathways can be attenuated by pre-incubation with antioxidants and tyrosine kinase inhibitors. ${ }^{57}$

ROS mediated effect in cardiovascular disease is also reflected in nuclear transcription factor activity. The nuclear transcription factor NFKB activity has been found in myocardial biopsies of patients with unstable angina. ${ }^{129}$ Nuclear translocation of RelA has also been found to be increased in human coronary artery plaques. $^{130}$

The pathogenesis of atherosclerosis has been thought of as an inflammation-mediated process. ${ }^{131}$ Atherosclerosis is associated with increased levels of inflammatory markers including CRP, IL-6, ESR, TNF, homocysteine. ${ }^{132}$ Hormones and cytokines such as angiotensin II, PDGF and TNFalpha may increase ROS in atherosclerotic lesions by stimulating local vascular myocytes to produce ROS. ${ }^{133}$ Mitochondrial dysfunction and increase ROS production has also been shown to associate with early atherosclerotic lesion formation. ${ }^{134}$ Multiple cell populations in the vascular wall have been shown to both produce and be regulated by ROS signaling. ${ }^{135}$ Free oxygen radicals lead to increase vascular oxidizes LDL and increase adhesion molecule expression in endothelial cells, which result in inflammatory cell infiltration and activate matrix metalloproteinases and vascular remodelling. ${ }^{136}$ Reactive oxygen species $\left(\mathrm{O}_{2}-\right.$ and $\left.\mathrm{H}_{2} \mathrm{O}_{2}\right)$ regulate growth and migration of vascular smooth muscle cells in the plaque structure. ${ }^{42}$ ROS also trigger extracellular matrix remodelling through regulation of collagen resorption resulting in compromised plaque stability. ${ }^{136,137}$

Oxidative/nitrosative stress and heart failure. Xanthine oxygenase is an important cardiovascular source of ROS. Increase in xanthine oxygenase level and activity has been shown in heart failure. ${ }^{138}$ Upregulation of xanthine oxygenase in patients with heart failure is thought to contribute to mechano-energetic uncoupling. ${ }^{139}$

$\mathrm{NAD}(\mathrm{P}) \mathrm{H}$ activity is also increased in cardiovascular disease with increased levels found in myocardial cells from humans with heart failure and in ischaemia-reperfusion models. ${ }^{140}$ This increase is due in part by elevated levels of angiotensin II which causes neurohormonal dysregulation of oxidative/nitrosative disequilibrium. ${ }^{141}$ In rabbit model of early atherosclerosis, where hypercholesterolemia was induced by defect in LDL-receptor, it was shown that $\mathrm{NAD}(\mathrm{P}) \mathrm{H}$-induced ROS production increased by 2 fold in the disease group compared with controls. ${ }^{142}$

Nitrosative stress caused by nitrogen free radicals also plays a role in cardiovascular disease. In acute ischaemia, sepsis or 


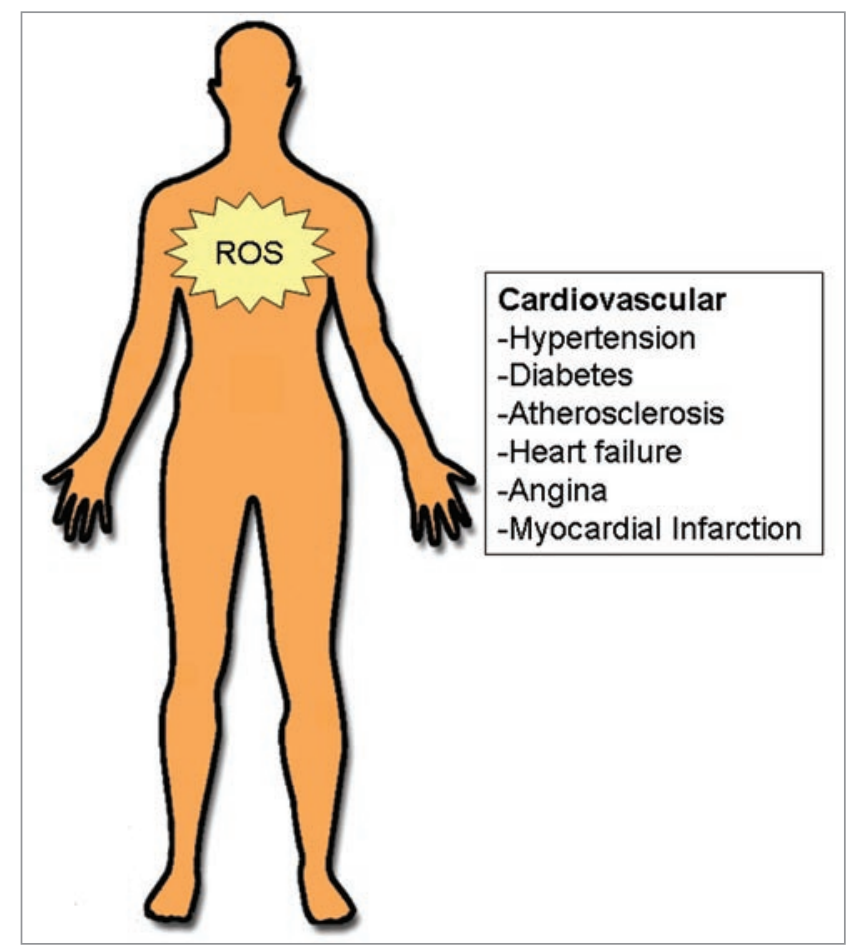

Figure 4. Recent emerging work supports with more overt evidence thus showing the strong relation of human disease mechanisms to the production of reactive oxidant species and the dysregulation of oxidantantioxidants pathways. These pathways as discussed in this review demonstrate the modulation of signal transduction processes and energy metabolism in response to conditions of oxidative/nitrosative stress.

heart failure, nitrosative stress is increased due to an increase in the amount of iNOS (NOS2), leading to increased levels of S-nitrosylated proteins. ${ }^{143}$ The accumulation of heme NO in heart failure is correlated with venous desaturation. ${ }^{144}$ Oxidative stress leads to partial uncoupling of eNOS, resulting in the increased production of superoxide and peroxynitrite species. ${ }^{145}$ However, the role of NOS activity in cardiovascular disease is not fully understood in that, although NOS gene therapy in carotid arteries of a rabbit model of hypercholesterolemia has been shown to rapidly reduce adhesion molecule expression and inflammatory cell infiltrations, ${ }^{146}$ in contrast, eNOS-deficient mice are known to develop smaller aortic lesions than corresponding wild-type control animals fed on an atherogenic diet. It is suggested that superoxide production by eNOS is important in oxidation of LDL during the formation of atherosclerosis in the setting of hyperlipidemia. ${ }^{147}$

The "Vascular Interaction With Age in Myocardial Infarction" (VINTAGE MI) Trial showed that supplementation of L-arginine (precursor of NO) in patients with first ST-segment

research with a clearer focus on the development of disease-specific therapeutic targets is required. elevation myocardial infarction did not improve vascular dynamics or cardiac function and may be associated with higher postinfarction mortality. ${ }^{144}$

In addition to direct injury, $\mathrm{NO} /$ redox disequilibrium may also impair ion channels within the heart by S-nitrosylation, resulting in functional cardiac impairment. ${ }^{143}$ Different NOS isoforms exert varying effects on cardiac physiology. For instance, NOS3 exert its effect on signal transduction at plasmalemmal membrane, inhibiting L-type calcium channel and thus attenuating the beta-adrenergic mediated myocardial contractility. ${ }^{148} \mathrm{On}$ the other hand, NOS1 isoform exerts its effect on sarcoplasmic reticulum, which facilitates calcium cycling and enhancing myocardial contractility stimulated by catecholamines. ${ }^{149}$

Oxidative/nitrosative stress and postoperative arrhythmias. Atrial fibrillation (AF) is a frequent complication of most types of coronary artery surgery. ${ }^{150}$ The incidence of post-operative AF (PAF) in patients undergoing cardiac surgery is between $20-50 \%$, and has been reported up to $65 \% .{ }^{150}$ It usually occurs within 5 days especially on the second or third day. ${ }^{151,152}$ The incidence may in fact be higher in patients with combined coronary artery bypass graft (CABG) and valve surgery than CABG alone. ${ }^{152,153}$ There is now a new focus on cardiac specific ROS production, rather than supplementing a systemic antioxidant response with evidence suggesting that myocardial specific-oxidative stress may be the main trigger for PAF. ${ }^{154}$ Recent evidence suggests that preoperative angiotensin converting enzyme inhibitor or angiotensin receptor blocker use has a significant impact on the frequency of atrial fibrillation after cardiac surgery, ${ }^{155}$ most likely by targeting cardiovascular specific ROS production.

\section{Concluding Remarks}

In recent times, important milestones have been reached with the availability of more overt evidence that shows that cardiovascular disease mechanisms are strongly linked to the production of reactive oxidant species and the dysregulation of oxidant-antioxidants pathways. In this regard, the oxidation and nitration of cellular proteins, lipids and nucleic acids, and formation of aggregates of oxidised molecules underlie the loss of cellular function, cellular ageing and the inability of cells to withstand physiological stresses. In addition, reactive oxidants species modulate signal transduction processes and energy metabolism in response to conditions of oxidative/nitrosative stress. Evidence shows that sources of reactive oxidant species, physiological and pathophysiological conditions, and cellular oxidant targets determine the characteristic nature of a disease process and resultant outcomes. Although much information on the relationship between oxidative stress and the disease process is now available (Fig. 4), further

\section{References}

1. Gutteridge JM, Halliwell B. Free radicals and antioxidants in the year 2000. A historical look to the future. Ann N Y Acad Sci 2000; 899:136-47.

2. Elahi MM, Matata BM. Free radicals in blood: evolving concepts in the mechanism of ischemic heart disease. Arch Biochem Biophys 2006; 450:78-88.
3. Pacher P, Szabo C. Role of the peroxynitritepoly(ADP-ribose) polymerase pathway in human disease. Am J Pathol 2008; 173:2-13.

4. Vassalle C, Pratali L, Boni C, Mercuri A, Ndreu R. An oxidative stress score as a combined measure of the pro-oxidant and anti-oxidant counterparts in patients with coronary artery disease. Clin Biochem 2008; 41:1162-7. 
5. Valko M, Rhodes CJ, Moncol J, Izakovic M, Mazur $M$. Free radicals, metals and antioxidants in oxidative stress-induced cancer. Chem Biol Interact 2006; 160:1-40.

6. Valko M, Morris H, Cronin MT. Metals, toxicity and oxidative stress. Curr Med Chem 2005; 12:1161208.

7. Jang S, Imlay JA. Micromolar intracellular hydrogen peroxide disrupts metabolism by damaging ironsulfur enzymes. J Biol Chem 2007; 282:929-37.

8. Tatton W, Chalmers-Redman R, Tatton N. Neuroprotection by deprenyl and other propargylamines: glyceraldehyde-3-phosphate dehydrogenase rather than monoamine oxidase B. J Neural Transm 2003; 110:509-15.

9. Tsutsui H, Kinugawa S, Matsushima S. Mitochondrial oxidative stress and dysfunction in myocardial remodelling. Cardiovasc Res 2009; 81:449-56.

10. Elahi MM, Naseem KM, Matata BM. Nitric oxide in blood. The nitrosative-oxidative disequilibrium hypothesis on the pathogenesis of cardiovascular disease. Febs J 2007; 274:906-23.

11. Ridnour LA, Thomas DD, Mancardi D, Espey MG, Miranda KM, Paolocci N, et al. The chemistry of nitrosative stress induced by nitric oxide and reactive nitrogen oxide species. Putting perspective on stressful biological situations. Biol Chem 2004; 385:1-10.

12. Ferreira SM, Lerner SF, Brunzini R, Evelson PA, Llesuy SF. Oxidative stress markers in aqueous humor of glaucoma patients. Am J Ophthalmol 2004; 137:62-9.

13. Dröge W. Free radicals in the physiological control of cell function. Physiol Rev 2002; 82:47-95.

14. Vassalle C, Pratali L, Boni C, Mercuri A, Ndreu R. An oxidative stress score as a combined measure of the pro-oxidant and anti-oxidant counterparts in patients with coronary artery disease. Clin Biochem 2008; 41:1162-7.

15. Cadenas E, Davies KJ. Mitochondrial free radical generation, oxidative stress and aging. Free Radic Biol Med 2000; 29:222-30.

16. Korge P, Ping P, Weiss JN. Reactive oxygen species production in energized cardiac mitochondria during hypoxia/reoxygenation: modulation by nitric oxide. Circ Res 2008; 103:873-80.

17. Kovacic P, Pozos RS, Somanathan R, Shangari N, O'Brien PJ. Mechanism of mitochondrial uncouplers, inhibitors and toxins: focus on electron transfer, free radicals and structure-activity relationships. Curr Med Chem 2005; 12:2601-23.

18. Muller FL, Liu Y, Van Remmen H. Complex III releases superoxide to both sides of the inner mitochondrial membrane. J Biol Chem 2004; 279:4906473.

19. De Marchi U, Mancon M, Battaglia V, Ceccon S, Cardellini P, Toninello A. Influence of reactive oxygen species production by monoamine oxidase activity on aluminium-induced mitochondrial permeability transition. Cell Mol Life Sci 2004; 61:2664-71.

20. Bodrova ME, Brailovskaya IV, Efron GI, Starkov AA, Mokhova EN. Cyclosporin A-sensitive decrease in the transmembrane potential across the inner membrane of liver mitochondria induced by low concentrations of fatty acids and $\mathrm{Ca}^{2+}$. Biochemistry 2003; 68:3918.

21. Du XL, Edelstein D, Dimmeler S, Ju Q, Sui C, Brownlee M. Hyperglycaemia inhibits endothelial nitric oxide synthase activity by posttranslational modification at the Akt site. J Clin Invest 2001; 108:1341-8.

22. Liu Y, Zhao H, Li H, Kalyanaraman B, Nicolosi AC, Gutterman DD. Mitochondrial sources of $\mathrm{H}_{2} \mathrm{O}_{2}$ generation play a key role in flow-mediated dilation in human coronary resistance arteries. Circ Res 2003; 93:573-80.
23. Ishida I, Kubo H, Suzuki S, Suzuki T, Akashi S, Inoue $\mathrm{K}$, et al. Hypoxia diminishes toll-like recepto 4 expression through reactive oxygen species generated by mitochondria in endothelial cells. J Immunol 2002; 169:2069-75.

24. Decoursey TE, Ligeti E. Regulation and termination of NADPH oxidase activity. Cell Mol Life Sci 2005; 62:2173-93.

25. Ungvari Z, Csiszar A, Huang A, Kaminski PM, Wolin MS, Koller A. High pressure induces superoxide production in isolated arteries via protein kinase $\mathrm{C}$-dependent activation of $\mathrm{NAD}(\mathrm{P}) \mathrm{H}$ oxidase. Circulation 2003; 108:1253-8.

26. Duerrschmidt N, Stielow C, Muller G, Pagano PJ, Morawietz $\mathrm{H}$. NO-mediated regulation of NAD $(\mathrm{P})$ $\mathrm{H}$ oxidase by laminar shear stress in human endothelial cells. J Physiol 2006; 576:557-67.

27. Li JM, Wheatcroft S, Fan LM, Kearney MT, Shah AM. Opposing roles of $\mathrm{p} 47$ phox in basal versus angiotensin II-stimulated alterations in vascular $\mathrm{O}_{2}$ production, vascular tone and mitogen-activated protein kinase activation. Circulation 2004; 109:1307 13.

28. Meier B. Regulation of the superoxide releasing system in human fibroblasts. Adv Exp Med Biol 1996; 387:113-6

29. Yang $M$, Kahn AM. Insulin-stimulated NADH/ $\mathrm{NAD}^{+}$redox state increases NAD $(\mathrm{P}) \mathrm{H}$ oxidase activity in cultured rat vascular smooth muscle cells. Am J Hypertens 2006; 19:587-92

30. Manea A, Manea SA, Gafencu AV, Raicu M, Simionescu M. AP-1-dependent transcriptional regulation of NADPH oxidase in human aortic smooth muscle cells: role of p22phox subunit. Arterioscler Thromb Vasc Biol 2008; 28:878-85.

31. Jung O, Marklund SL, Geiger H, Pedrazzini T, Busse R, Brandes RP. Extracellular superoxide dismutase is a major determinant of nitric oxide bioavailability: in vivo and ex vivo evidence from ecSOD-deficient mice. Circ Res 2003; 93:622-9.

32. Bassenge E, Sommer O, Schwemmer M, Bünger R. Antioxidant pyruvate inhibits cardiac formation of reactive oxygen species through changes in redox state. Am J Physiol Heart Circ Physiol 2000; 279:2431-8.

33. Holland JA, O'Donnell RW, Chang MM, Johnson DK, Ziegler LM. Endothelial cell oxidant production: effect of NADPH oxidase inhibitors. Endothelium 2000; 7:109-19.

34. Guzik TJ, West NE, Black E, McDonald D, Ratnatunga C, Pillai R, Channon KM. Vascular superoxide production by $\mathrm{NAD}(\mathrm{P}) \mathrm{H}$ oxidase: association with endothelial dysfunction and clinical risk factors. Circ Res 2000; 86:85-90.

35. Zhao W, Zhao D, Yan R, Sun Y. Cardiac oxidative stress and remodeling following infarction: role of NADPH oxidase. Cardiovasc Pathol 2009; 18:156 66.

36. Borges F, Fernandes E, Roleira F. Progress towards the discovery of xanthine oxidase inhibitors. Curr Med Chem 2002; 9:195-217

37. Vorbach C, Harrison R, Capecchi MR. Xanthine oxidoreductase is central to the evolution and function of the innate immune system. Trends Immunol 2003; 24:512-7.

38. Sumi D, Hayashi T, Thakur NK, Jayachandran M, Asai Y, Kano H, et al. A HMG-CoA reductase inhibitor possesses a potent anti-atherosclerotic effect other than serum lipid lowering effects-the relevance of endothelial nitric oxide synthase and superoxide anion scavenging action. Atherosclerosis 2001; 155:347-57.
39. Scotland RS, Chauhan S, Vallance PJ, Ahluwalia A An endothelium-derived hyperpolarizing factor-like factor moderates myogenic constriction of mesenteric resistance arteries in the absence of endothelial nitric oxide synthase-derived nitric oxide. Hypertension 2001; 38:833-9.

40. Grobe AC, Wells SM, Benavidez E, Oishi P, Azakie A, Fineman JR, Black SM. Increased oxidative stress in lambs with increased pulmonary blood flow and pulmonary hypertension: role of NADPH oxidase and endothelial NO synthase. Am J Physiol Lung Cell Mol Physiol 2006; 290:1069-77.

41. Schulz E, Jansen T, Wenzel P, Daiber A, Münzel T. Nitric oxide, tetrahydrobiopterin, oxidative stress and endothelial dysfunction in hypertension. Antioxid Redox Signal 2008; 10:1115-26.

42. Ghafourifar P, Asbury ML, Joshi SS, Kincaid ED. Determination of mitochondrial nitric oxide synthase activity. Methods Enzymol 2005; 396:424-44.

43. Touyz RM, Schiffrin EL. Reactive oxygen species in vascular biology: implications in hypertension. Histochem Cell Biol 2004; 122:339-52.

44. Vásquez-Vivar J, Kalyanaraman B, Martásek P, Hogg N, Masters BS, Karoui H, et al. Superoxide generation by endothelial nitric oxide synthase: the influence of cofactors. Proc Natl Acad Sci USA 1998; 95:9220-5.

45. Laursen JB, Somers M, Kurz S, McCann L, Warnholtz A, Freeman BA, et al. Endothelial regulation of vasomotion in apoE-deficient mice: implications for interactions between peroxynitrite and tetrahydrobiopterin. Circulation 2001; 103:1282-8.

46. Böger RH, Bode-Böger SM, Tsao PS, Lin PS, Chan JR, Cooke JP. An endogenous inhibitor of nitric oxide synthase regulates endothelial adhesiveness for monocytes. J Am Coll Cardiol 2000; 36:2287-95.

47. Touyz RM, Schiffrin EL. Reactive oxygen species in vascular biology: implications in hypertension. Histochem Cell Biol 2004; 122:339-52.

48. Shinyashiki M, Pan CJ, Lopez BE, Fukuto JM. Inhibition of the yeast metal reductase heme protein frel by nitric oxide (NO): a model for inhibition of NADPH oxidase by NO. Free Radic Biol Med 2004; 37:713-23

49. Pritchard KA Jr, Groszek L, Smalley DM, Sessa WC Wu M, Villalon P, et al. Native low-density lipoprotein increases endothelial cell nitric oxide synthase generation of superoxide anion. Circ Res 1995; 77:510-8.

50. Laursen JB, Boesgaard S, Trautner S, Rubin I, Poulsen HE, Aldershvile J. Endothelium-dependent vasorelaxation in inhibited by in vivo depletion of vascular thiol levels: role of endothelial nitric oxide synthase. Free Radic Res 2001; 35:387-94.

51. Cadenas E, Davies KJ. Mitochondrial free radical generation, oxidative stress and aging. Free Radic Biol Med 2000; 29:222-30.

52. Heitzer T, Schlinzig T, Krohn K, Meinertz T, Münzel T. Endothelial dysfunction, oxidative stress and risk of cardiovascular events in patients with coronary artery disease. Circulation 2001; 104:2673-8.

53. Touyz RM. Reactive oxygen species as mediators of calcium signaling by angiotensin II: implications in vascular physiology and pathophysiology. Antioxid Redox Signal 2005; 7:1302-14.

54. Xu Q, Konta T, Nakayama K, Furusu A, MorenoManzano V, Lucio-Cazana J, et al. Cellular defense against $\mathrm{H}_{2} \mathrm{O}_{2}$-induced apoptosis via MAP kinaseMKP-1 pathway. Free Radic Biol Med 2004; 36:98593.

55. Bhunia AK, Han H, Snowden A, Chatterjee S. Redox-regulated signaling by lactosylceramide in the proliferation of human aortic smooth muscle cells. J Biol Chem 1997; 272:15642-9.

56. Kim S, Denny CT, Wisdom R. Cooperative DNA binding with AP-1 proteins is required for transformation by EWS-Ets fusion proteins. Mol Cell Biol $2006 ; 26: 2467-78$. 
57. Winyard PG, Blake DR. Antioxidants, redox-regulated transcription factors and inflammation. Adv Pharmacol 1997; 38:403-21.

58. Bonizzi G, Karin M. The two NFkappaB activation pathways and their role in innate and adaptive immunity. Trends Immunol 2004; 25:280-8.

59. Imbert V, Rupec RA, Livolsi A, Pahl HL, Traenckner EB, Mueller-Dieckmann C, et al. Tyrosine phosphorylation of IkappaBalpha activates NFkappaB without proteolytic degradation of IkappaBalpha. Cell 1996; 86:787-98.

60. Baeuerle PA, Henkel T. Function and activation of NFkappaB in the immune system. Annu Rev Immunol 1994; 12:141-79.

61. Traenckner EB, Pahl HL, Henkel T, Schmidt KN Wilk S, Baeuerle PA. Phosphorylation of human IkappaBalpha on serines 32 and 36 controls IkappaBalpha proteolysis and NFkappaB activation in response to diverse stimuli. EMBO J 1995; 14:2876-83.

62. Jeay S, Pianetti S, Kagan HM, Sonenshein GE. Lysyl oxidase inhibits ras-mediated transformation by preventing activation of NFkappaB. Mol Cell Biol 2003; 23:2251-63.

63. Mattson D, Bradbury CM, Bisht KS, Curry HA, Spitz DR, Gius D. Heat shock and the activation of AP-1 and inhibition of NFkappaB DNA-binding activity: possible role of intracellular redox status. Int J Hyperthermia 2004; 20:224-33.

64. Allport VC, Slater DM, Newton R, Bennett PR. NFkappaB and AP-1 are required for cyclo-oxygenase 2 gene expression in amnion epithelial cell line (WISH). Mol Hum Reprod 2000; 6:561-5.

65. Yeung F, Hoberg JE, Ramsey CS, Keller MD, Jones DR, Frye RA, Mayo MW. Modulation of NFkappaB-dependent transcription and cell survival by the SIRT1 deacetylase. EMBO J 2004; 23:236980.

66. Howitz KT, Bitterman KJ, Cohen HY, Lamming DW, Lavu S, Wood JG, et al. Small molecule activators of sirtuins extend Saccharomyces cerevisiae lifespan 2003; 425:191-6.

67. Zingarelli B. Nuclear factor-kappaB. Crit Care Med 2005; 33:414-6.

68. Monaco C, Paleolog E. Nuclear factor kappaB: a potential therapeutic target in atherosclerosis and thrombosis. Cardiovasc Res 2004; 61:671-82.

69. Brand K, Page S, Walli AK, Neumeier D, Baeuerle PA. Role of nuclear factor-kappaB in atherogenesis. Exp Physiol 1997; 82:297-304

70. Mach F, Schonbeck U, Libby P. CD40 signaling in vascular cells: a key role in atherosclerosis? Atherosclerosis 1998; 137:89-95.

71. Kawano S, Kubota T, Monden Y, Tsutsumi T, Inoue T, Kawamura N, et al. Blockade of NFkappaB improves cardiac function and survival after myocardial infarction. Am J Physiol Heart Circ Physio 2006; 291:1337-44

72. Landry DB, Couper LL, Bryant SR, Lindner V. Activation of the NFkappaB and IkappaB system in smooth muscle cells after rat arterial injury. Induction of vascular cell adhesion molecule-1 and monocytes chemoattractant protein-1. Am J Pathol 1997; 151:1085-95.

73. Barlic J, Zhang Y, Murphy PM. Atherogenic lipids induce adhesion of human coronary artery smooth muscle cells to macrophages by upregulating chemokine CX3CL1 on smooth muscle cells in a TNFalpha-NFkappaB-dependent manner. J Biol Chem 2007; 282:19167-76.

74. Huang WC, Chen JJ, Inoue H, Chen CC. Tyrosine phosphorylation of IkappaB kinase alpha/beta by protein kinase $\mathrm{C}$-dependent c-Src activation is involved in TNFalpha-induced cyclooxygenase- 2 expression. J Immunol 2003; 170:4767-75.
75. Calara F, Dimayuga P, Niemann A, Thyberg J, Diczfalusy U, Witztum JL, et al. An animal model to study local oxidation of LDL and its biological effects in the arterial wall. Arterioscler Thromb Vasc Biol 1998; 18:884-93.

76. Bierhaus A, Illmer $T$, Kasper $M$, Luther $T$, Quehenberger $\mathrm{P}$, Tritschler $\mathrm{H}$, et al. Advanced Glycation End Product (AGE) mediated Induction of Tissue Factor in Cultured Endothelial Cells Is Dependent on RAGE. Circulation 1997; 96:226271

77. Han Y, Runge MS, Brasier AR. Angiotensin II induces interleukin-6 transcription in vascular smooth muscle cells through pleotropic activation of nuclear factor-kappaB transcription factors. Circ Res 1999; 84:695-703.

78. Vink A, Schoneveld AH, van der Meer JJ, van Middelaar BJ, Sluijter JPG, Smeets MB, et al. In Vivo Evidence for a Role of Toll-Like Receptor 4 in the Development of Intimal Lesions. Circulation 2002; 106:1985-90

79. Khanal P, Lee KY, Kang KW, Kang BS, Choi HS Tpl-2 kinase downregulates the activity of p53 and enhances signaling pathways leading to activation of activator protein 1 induced by EGF. Carcinogenesis 2009; 30:682-9.

80. Guberman AS, Scassa ME, Giono LE, Varone CL, Cánepa ET. Inhibitory effect of AP-1 complex on 5 -aminolevulinate synthase gene expression through sequestration of cAMP-response element protein (CRE)-binding protein (CBP) coactivator. Biol Chem 2003; 278:2317-26.

81. Amstad PA, Krupitza G, Cerutti PA. Mechanism of c-fos induction by active oxygen. Cancer Res 1992; 52:3952-60.

82. Buscher M, Rahmsdorf HJ, Litfin $M$, Karin $M$, Herrlich P. Activation of the c-fos gene by UV and phorbol ester: different signal transduction pathways converge to the same enhancer element. Oncogene 1988; 3:301-11

83. Lander HM, Ogiste JS, Teng KK, Novogrodsky A. p21ras as a common signaling target of reactive free radicals and cellular redox stress. J Biol Chem 1995 ; 270:21195-8

84. Angel P, Karin M. The role of Jun, Fos and the AP-1 complex in cell-proliferation and transformation. Biochim Biophys Acta 1991; 1072:129-57.

85. Rubbo H, O'Donnell V. Nitric oxide, peroxynitrite and lipoxygenase in atherogenesis: mechanistic insights. Toxicology 2005; 208:305-17.

86. Gomez del Arco P, Martinez-Martinez S, Calvo V, Armesilla AL, Redondo JM. Antioxidants and AP-1 activation: a brief overview. Immunobiology 1997 198:273-8

87. Winyard PG, Moody CJ, Jacob C. Oxidative activation of antioxidant defence. Trends Biochem Sci 2005; 30:453-61.

88. Keller H, Dreyer C, Medin J, Mahfoudi A, Ozato K, Wahli W. Fatty acids and retinoids control lipid metabolism through activation of peroxisome proliferator-activated receptor-retinoid X receptor heterodimers. Proc Natl Acad Sci USA 1993; 90:2160

89. Marx N, Bourcier T, Sukhova GK, Libby P, Plutzky J. PPAR \{gamma\} Activation in Human Endothelia Cells Increases Plasminogen Activator Inhibitor Type-1 Expression: PPAR \{gamma\} as a Potential Mediator in Vascular Disease. Arterioscler Thromb Vasc Biol 1999; 19:546-51.

90. Staels B, Koenig W, Habib A, Merval R, Lebret M, Torra IP, et al. Activation of human aortic smoothmuscle cells is inhibited by PPARalpha but not by PPARgamma activators. Nature 1998; 393:790-3.

91. Manna SK, Aggarwal BB. Differential requirement for p56lck in HIV-tat versus TNF-induced cellula responses: effects on NFkappaB, activator protein-1, c-Jun $\mathrm{N}$-terminal kinase and apoptosis. J Immunol $2000 ; 164: 5156-66$
92. Rieber P, Baeuerle PA. Reactive oxygen intermediates as apparently widely used messengers in the activation of the NFkappaB transcription factor and HIV1. EMBO J 1991; 10:2247-58.

93. Haynes WG, Webb DJ. Contribution of endogenous generation of endothelin-1 to basal vascular tone. Lancet 1994; 344:852-4.

94. Forrester JS, Litvack F, Grundfest W. Initiating events of acute coronary arterial occlusion. Annu Rev Med 1991; 42:35-45.

95. Zorio E, Gilabert-Estellés J, España F, Ramón LA, Cosín R, Estellés A. Fibrinolysis: the key to new pathogenetic mechanisms. Curr Med Chem 2008; 15:923-9.

96. Zeiher AM, Drexler $\mathrm{H}$, Wollschlager $\mathrm{H}$, Just $\mathrm{H}$. Endothelial dysfunction of the coronary microvasculature is associated with coronary blood flow regulation in patients with early atherosclerosis. Circulation 1991; 84:1984-92.

97. Sakai T, Inoue S, Matsuyama TA, Takei M, Ota H, Katagiri T, Koboyashi Y. Eosinophils may be involved in thrombus growth in acute coronary syndrome. Int Heart J 2009; 50:267-77.

98. Fraley AE, Schwartz GG, Olsson AG, Kinlay S, Szarek M, Rifai N, et al. MIRACL Study Investigators. Relationship of oxidized phospholipids and biomarkers of oxidized low-density lipoprotein with cardiovascular risk factors, inflammatory biomarkers, and effect of statin therapy in patients with acute coronary syndromes: Results from the MIRACL (Myocardial Ischemia Reduction With Aggressive Cholesterol Lowering) trial. J Am Coll Cardiol 2009; 53:2186-96.

99. Heitzer T, Schlinzig T, Krohn K, Meinertz T, Munzel T. Endothelial dysfunction, oxidative stress and risk of cardiovascular events in patients with coronary artery disease. Circulation 2001; 104:2673-8.

100. Schachinger V, Zeiher AM. Alterations of coronary blood flow and myocardial perfusion in hypercholesterolemia. Heart 1996; 76:295-8.

101. Celermajer DS, Sorensen KE, Georgakopoulos D, Bull C, Thomas O, Robinson J, Deanfield JE. Cigarette smoking is associated with dose-related and potentially reversible impairment of endothelium-dependent dilation in healthy young adults. Circulation 1993; 88:2149-55.

102. Heitzer T, Just H, Munzel T. Antioxidant vitamin C improves endothelial dysfunction in chronic smokers. Circulation 1996; 94:6-9

103. Swei A, Lacy F, DeLano FA, Schmid-Schonbein GW. Oxidative stress in the Dahl hypertensive rat. Hypertension 1997; 30:1628-33.

104. Alexander RW. Theodore Cooper Memorial Lecture. Hypertension and the pathogenesis of atherosclerosis. Oxidative stress and the mediation of arterial inflammatory response: a new perspective. Hypertension 1995; 25:155-61.

105. Zeiher AM, Schachlinger V, Hohnloser SH, Saurbier $\mathrm{B}$, Just $\mathrm{H}$. Coronary atherosclerotic wall thickening and vascular reactivity in humans. Elevated high-density lipoprotein levels ameliorate abnormal vasoconstriction in early atherosclerosis. Circulation 1994; 89:2525-32.

106. Schachinger V, Zeiher AM. Quantitative Assessment of Coronary Vasoreactivity in Humans In Vivo: Importance of Baseline Vasomotor Tone in Atherosclerosis. Circulation 1995; 92:2087-94.

107. Harrison DG. Endothelial function and oxidant stress. Clin Cardiol 1997; 20:11-7.

108. Moroi M, Zhang L, Yasuda T, Virmani R, Gold HK, Fishman MC, Huang PL. Interaction of genetic deficiency of endothelial nitric oxide, gender and pregnancy in vascular response to injury in mice. J Clin Invest 1998; 101:1225-32. 
109. Antoniades C, Shirodaria C, Warrick N, Cai S, de Bono J, Lee J, et al. 5-Methyltetrahydrofolate Rapidly Improves Endothelial Function and Decreases Superoxide Production in Human Vessels: Effects on Vascular Tetrahydrobiopterin Availability and Endothelial Nitric Oxide Synthase Coupling. Circulation 2006; 114:1193-201.

110. Brandes RP, Barton M, Philippens KM, Schweitzer G, Mugge A. Endothelial-derived superoxide anions in pig coronary arteries: evidence from lucigenin chemiluminescence and histochemical techniques. J Physiol 1997; 500:331-42.

111. Lerman A, Burnett JC Jr, Higano ST, McKinley LJ, Holmes DR Jr. Long-term L-Arginine Supplementation Improves Small-Vessel Coronary Endothelial Function in Humans. Circulation 1998; 97:2123-8.

112. Nisoli E, Tonello C, Cardile A, Cozzi V, Bracale $\mathrm{R}$, Tedesco L, et al. Calorie Restriction Promotes Mitochondrial Biogenesis by Inducing the Expression of eNOS. Science 2005; 310:314-7.

113. McMahon TJ, Moon RE, Luschinger BP, Carraway MS, Stone AE, Stolp BW, et al. Nitric oxide in the human respiratory cycle. Nat Med 2002; 8:711-7.

114. Rubbo H, Tarpey M, Freeman BA. Nitric oxide and reactive oxygen species in vascular injury. Biochem Soc Symp1995; 61:33-45.

115. Cesselli D, Jakoniuk I, Barlucchi L, Beltrami AP, Hintze TH, Nadal-Ginard B, et al. Oxidative stressmediated cardiac cell death is a major determinant of ventricular dysfunction and failure in dog dilated cardiomyopathy. Circ Res 2001; 89:279-86.

116. Zheng JS, Yang XQ, Lookingland KJ. Gene transfer of human guanosine 5'-triphosphate cyclohydrolase I restores vascular tetrahydrobiopterin level and endothelial function in low renin hypertension. Circulation 2003; 108:1238-45.

117. Higashi Y, Sasaki S, Nakagawa K, Matsuura H, Oshima T, Chayama K. Endothelial function and oxidative stress in renovascular hypertension. $\mathrm{N}$ Engl J Med 2002; 346:1954-62.

118. Lip GY, Edmunds E, Nuttall SL, Landray MJ, Blann AD, Beevers DG. Oxidative stress in malignant and non-malignant phase hypertension. J Hum Hypertens 2002; 16:333-6.

119. Lee VM, Quinn PA, Jennings SC, Ng LL. Neutrophil activation and production of reactive oxygen species in pre-eclampsia. J Hypertens 2003; 21:395-402.

120. Lassegue B, Clempus RE. Vascular NAD (P)H oxidases: specific features, expression and regulation. Am J Physiol Regul Integr Comp Physiol 2003; 285:277-97.

121. John JH, Ziebland S, Yudkin P, Roe LS, Neil HAW. Effects of fruit and vegetable consumption on plasma antioxidant concentrations and blood pressure: a randomized controlled trial. Lancet 2002; 359:1969-73.

122. Ghiadoni L, Magagna A, Versari D, Kardasz I, Huang Y, Taddei S, Salvetti A. Different effect of antihypertensive drugs on conduit artery endothelial function. Hypertension 2003; 41:1281-6.
123. Yoshida J, Yamamoto K, Mano T, Sakata Y, Nishikawa $\mathrm{N}$, Nishio $\mathrm{M}$, et al. AT receptor blocker added to ACE inhibitor provides benefits at advanced stage of hypertensive diastolic heart failure. Hypertension 2004; 43:686-91.

124. Paravicini TM, Touyz RM. NADPH oxidases, reactive oxygen species and hypertension: clinical implications and therapeutic possibilities. Diabetes Care 2008; 31:170-80.

125. Elahi M, Matata B. Blood-dependent Redox Activity During Extracorporeal Circulation in Health and Disease. The Cardiology 2005; 1:156-7.

126. Wilson SH, Best PJ, Edwards WD, Holmes DR Jr, Carlson PJ, Celermajer DS, Lerman A. Nuclear factor-kappaB immunoreactivity is present in human coronary plaque and enhanced in patients with unstable angina pectoris. Atherosclerosis 2002; 160:14753.

127. Ross R. Atherosclerosis-an inflammatory disease. N Engl J Med 1999; 340:115-26.

128. Elkind MS. Inflammation, atherosclerosis and stroke. Neurologist 2006; 12:140-8

129. Bonomini F, Tengattini S, Fabiano A, Bianchi R, Rezzani R. Atherosclerosis and oxidative stress. Histol Histopathol 2008; 23:381-90.

130. Harrison D, Griendling KK, Landmesser U, Hornig $\mathrm{B}$, Drexler H. Role of oxidative stress in atherosclerosis. Am J Cardiol 2003; 91:7-11.

131. Suzuki YJ, Ford GD. Redox regulation of signal transduction in cardiac and smooth muscle. J Mol Cell Cardiol 1999; 31:345-53.

132. Aviram M, Rosenblat M, Etzioni A, Levy R. Activation of NADPH oxidase required for macrophage-mediated oxidation of low-density lipoprotein. Metabolism 1996; 45:1069-79.

133. Chen XL, Tummala PE, Olbrych MT, Alexander RW, Medford RM. Angiotensin II induces monocytes chemoattractant protein-1 gene expression in rat vascular smooth muscle cells. Circ Res 1998; 83:952-9.

134. Griendling KK, Sorescu D, Ushio-Fukai M. NAD(P) $\mathrm{H}$ oxidase: role in cardiovascular biology and disease. Circ Res 2000; 86:494-501.

135. Cappola TP, Kass DA, Nelson GS, Berger RD, Rosas GO, Kobeissi ZA, et al. Allopurinol Improves Myocardial Efficiency in Patients With Idiopathic Dilated Cardiomyopathy. Circulation 2001; 104:2407-11.

136. Heymes C, Bendall JK, Ratajczak P, Cave AC, Samuel JL, Hasenfuss G, Shah AM. Increased myocardial NADPH oxidase activity in human heart failure. J Am Coll Cardiol 2003; 41:2164-71.

137. Maytin M, Siwik DA, Ito M, Xiao L, Sawyer DB, Liao R, Colucci WS. Pressure Overload-Induced Myocardial Hypertrophy in Mice Does Not Require gp91phox. Circulation 2004; 109:1168-71.

138. Warnholtz A, Nickenig G, Schulz E, Macharzina R, Brasen JH, Skatchkov M, et al. Increased NADHOxidase mediated Superoxide Production in the Early Stages of Atherosclerosis: Evidence for Involvement of the Renin-Angiotensin System. Circulation 1999; 99:2027-33.
139. Shinyashiki M, Pan CJ, Lopez BE, Fukuto JM. Inhibition of the yeast metal reductase heme protein frel by nitric oxide (NO): a model for inhibition of NADPH oxidase by NO. Free Radic Biol Med 2004; 37:713-23.

140. Foster MW, McMahon TJ, Stamler JS. S-nitrosylation in health and disease. Trends Mol Med 2003; 9:1608.

141. Cai H, Harrison DG. Endothelial dysfunction in cardiovascular diseases: the role of oxidant stress. Circ Res 2000; 87:840-4.

142. Qian HS, Neplioueva V, Shetty GA, Channon KM George SE. Nitric Oxide Synthase Gene Therapy Rapidly Reduces Adhesion Molecule Expression and Inflammatory Cell Infiltration in Carotid Arteries of Cholesterol-Fed Rabbits. Circulation 1999; 99:297982.

143. Shi W, Wang X, Shih DM, Laubach VE, Navab M, Lusis AJ. Paradoxical Reduction of Fatty Streak Formation in Mice Lacking Endothelial Nitric Oxide Synthase. Circulation 2002; 105:2078-82.

144. Schulman SP, Becker LC, Kass DA, Champion HC, Terrin ML, Forman S, et al. L-arginine therapy in acute myocardial infarction: the Vascular Interaction with Age in Myocardial Infarction (VINTAGE MI) randomized clinical trial. JAMA 2006; 295:58-64.

145. Bryan NS, Rassaf T, Maloney RE, Rodriguez CM, Saijo F, Rodriguez JR, Feelisch M. Cellular targets and mechanisms of nitros(yl)ation: An insight into their nature and kinetics in vivo. Proceedings of the National Academy of Sciences 2004; 101:4308-13.

146. Khan SA, Lee K, Minhas KM, Gonzalez DR, Raju SV, Tejani AD, et al. Neuronal nitric oxide synthase negatively regulates xanthine oxidoreductase inhibition of cardiac excitation-contraction coupling. Proc Natl Acad Sci USA 2004; 101:15944-8.

147. Brownlee M, Cerami A. The biochemistry of the complications of diabetes mellitus. Annu Rev Biochem 1981; 50:385-432.

148. Weyer C, Funahashi T, Tanaka S, Hotta K, Matsuzawa Y, Pratley RE, Tataranni PA. Hypoadiponectinemia in obesity and type 2 diabetes: close association with insulin resistance and hyperinsulinemia. J Clin Endocrinol Metab 2001; 86:1930-5.

149. Puig JG, Mateos FA, Diaz VD. Inhibition of xanthine oxidase by allopurinol: a therapeutic option for ischaemia induced pathological processes? Ann Rheum Dis 1989; 48:883-8.

150. Oral H. Post-operative atrial fibrillation and oxidative stress. A novel causal mechanism or another biochemical epiphenomenon? J Am Col Cardiol 2008; 51:75-6.

151. Auer J, Weber T, Berent R, Ng CK, Lamm G, Eber B. Risk factors of postoperative atrial fibrillation after cardiac surgery. J Card Surg 2005; 20:425-31.

152. Elahi M, Hadjinikolaou L, Galiñanes M. Incidence and clinical consequences of atrial fibrillation within 1 year of first-time isolated coronary bypass surgery. Circulation 2003; 108:207-12.

153. Hakala T, Hedman A. Predicting the risk of atrial fibrillation after coronary artery bypass surgery. Scand Cardiovasc J 2003; 37:309-15.

154. Neuman RB, Bloom HL, Shukrullah I, Darrow LA, Kleinbaum D, Jones DP, Dudley SC Jr. Oxidative stress markers are associated with persistent atrial fibrillation. Clin Chem 2007; 53:1652-7.

155. White CM, Kluger J, Lertsburapa K, Faheem O Coleman CI. Effect of preoperative angiotensin converting enzyme inhibitor or angiotensin receptor blocker use on the frequency of atrial fibrillation after cardiac surgery: a cohort study from the atrial fibrillation suppression trials II and III. Eur J Cardiothorac Surg 2007; 31:817-20. 


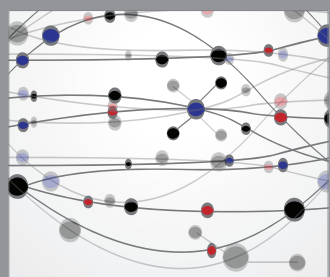

The Scientific World Journal
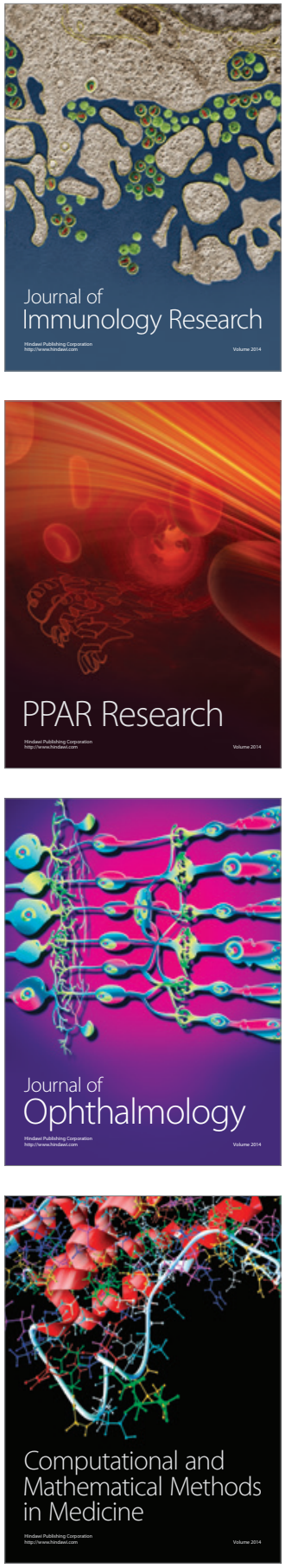

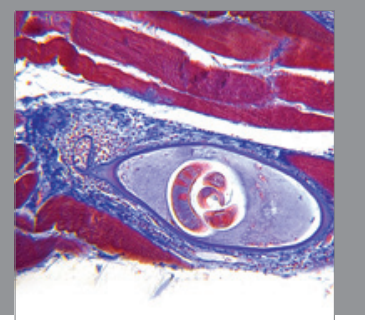

Gastroenterology

Research and Practice
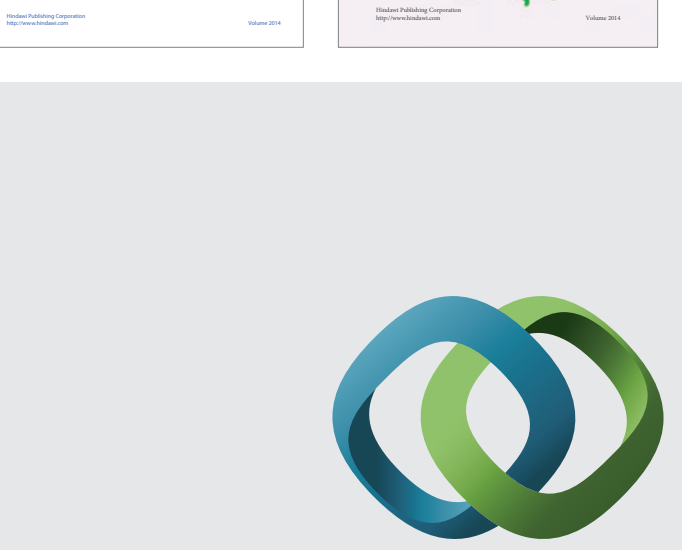

\section{Hindawi}

Submit your manuscripts at

http://www.hindawi.com
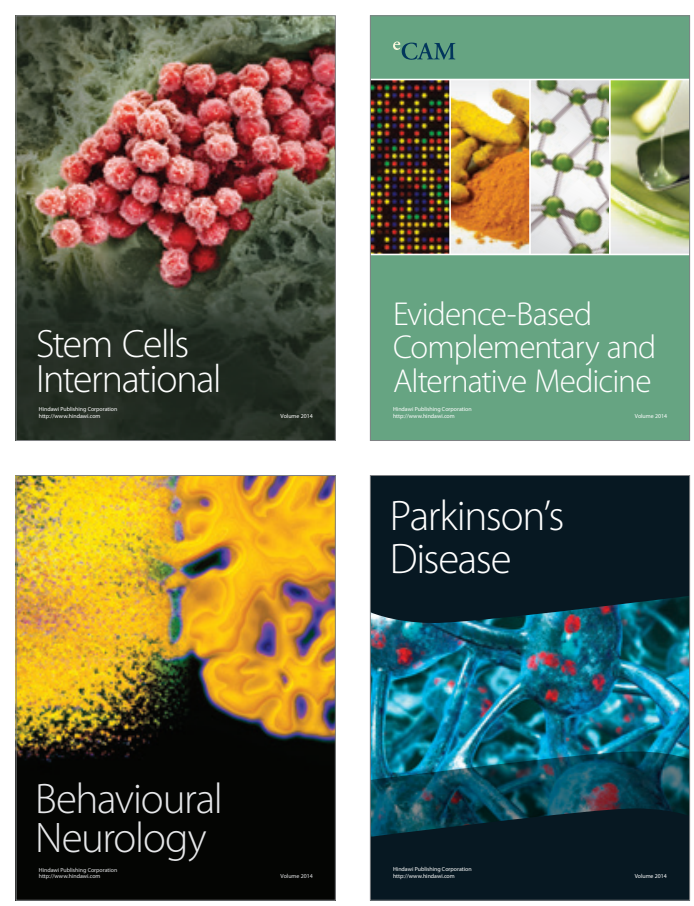

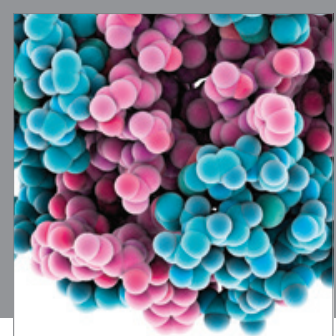

Journal of
Diabetes Research

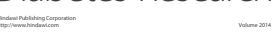

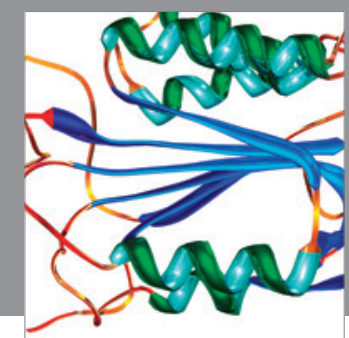

Disease Markers
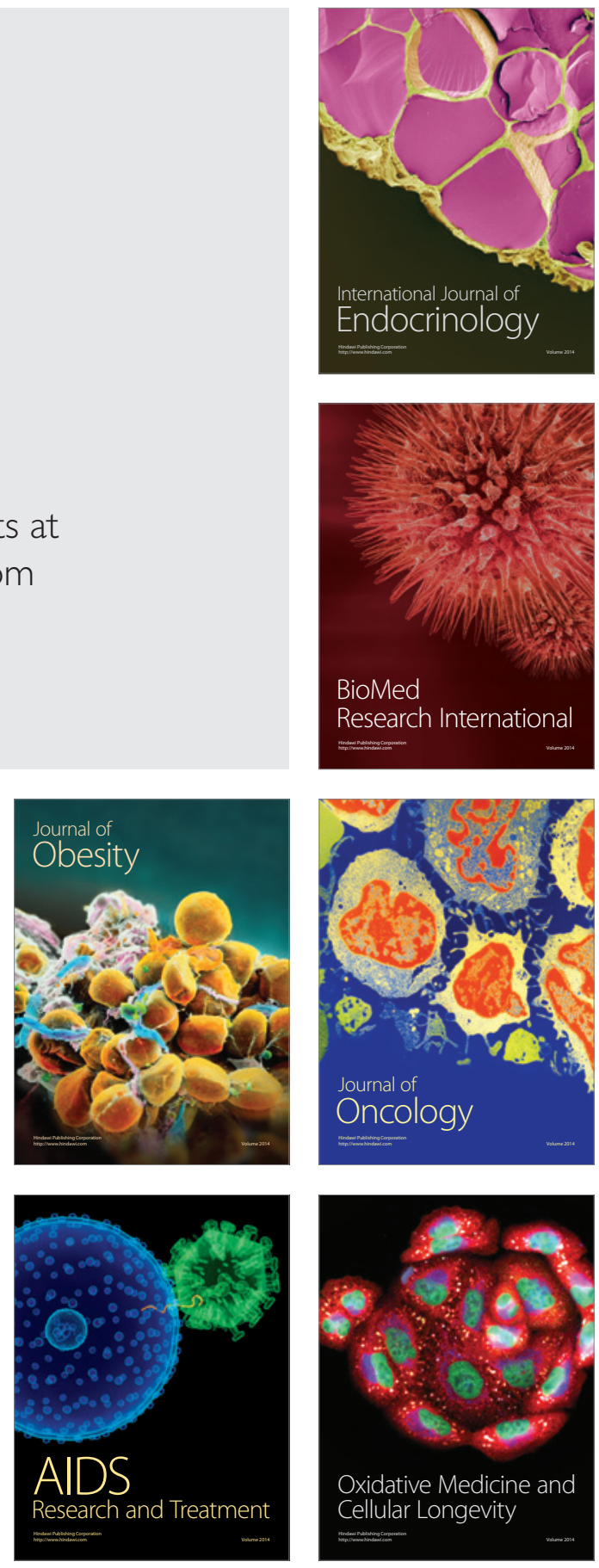